\title{
The Accumulation of Capital, by Investing in Mutual Funds
}

\author{
Adamova Karine \\ Department of Financial Markets and Financial Engineering, Financial University, Russia
}

Copyright (C) 2015 Horizon Research Publishing All rights reserved.

\begin{abstract}
Each of us during their working life should create a reserve of funds needed to ensure a secure and carefree old age in the future. The last 20 years, with independence, the citizens of the countries of the former USSR did accumulation of funds in various ways, but in most cases this led not to their growth, but mainly to the loss, while in the leading foreign countries, nationals of their savings not only ensure a decent life in old age, but made a huge contribution to the prosperity of their country in General. What is the accumulation? As we understand this concept, and as I see it abroad? The answers to these and many other questions do not lie only in their understanding, but in the psychological aspects invested in person at the time of its formation in the early years of life.
\end{abstract}

Keywords Savings, Mutual Funds, IMF, World Bank, Money Resources, Bank Deposit, Foreign Exchange and Stock Markets, Operations on Financial Markets

\section{Introduction}

In order to have funds for existence in old age, they must accumulate during their working life. In different countries it's done differently. In the USSR we took our spare money, and carried them to the Bank on a passbook under several percent per annum. Here it is necessary to note two important points. Despite the low percentage, we were convinced that the rouble will be stable and will have the constant purchasing power, and the state in time will pay us our savings. For the state it was also important. In view of the closeness of the economic system of the USSR, the country was in constant need of cash flows for new construction and industrial projects, while cheaper financial resources are not in the IMF or the World Bank, as of its own citizens.

What we got instead of that, since independence? Did we make a big economic freedom, and what we can do with their money? After independence, we, strange as it is, funds set aside for the future, don't invest in a private company and the world's leading corporations, we either derive outside the country, or kept at home under the flooring. It's to do with the fact that we are not allowed to invest in domestic and world economy, it is because we do not trust and do not have the minimum knowledge needed to more actively use their free money resources.

\section{Methodology and Discussion}

The impact of bankruptcies and financial turmoil, which we received in the early 1990s, closes our eyes to the opportunities enjoyed by ordinary citizens in the leading countries of the world. In Western Europe and North America, citizens from a very early age are taught to what you need to efficiently treat their funds and to use every opportunity in order to invest them in a variety of corporations and increase them in time. To Bank deposits abroad are a little different than we paid more attention to investing in the shares of different enterprises. In order to understand the difference, you need to understand the process of a Bank Deposit and investing directly in corporate stocks.

When funds are deposited into a Bank Deposit, the investor no longer interested in what will happen with them. Thanks Bank reserves, the client does not care whether the Bank to pay him his money, but for less risk you have to pay. This is reflected in the rate of Bank interest, which rarely exceeds $5 \%-7 \%$ per annum in the world's leading banks. What tools does the Bank? He them, on your own risk, invests in shares of various companies, or under a higher percentage issues in the form of various credit programs. In other words, banks, having studied various investment projects, choose the best, and there invests funds received from its customers.

Operations on financial markets, including foreign exchange and stock markets, the world's leading banks make up about $60 \%-70 \%$ of their total profits. So why waste any profit, giving it to the Bank, if it can be obtained by making too, which makes the Bank in its activities. In order to repeat the operation, no need to have a banking license and obtain advanced degrees in leading universities of the world, you 
should ask yourself processes taking place on the stock market and investment companies to carry out the same operations, while receiving a greater rate of return than Bank deposits.

This principle is best embodied in the life of the USA and Canada, which are among the first in the world to have imparted to the citizens of the desire and need to invest a large part of their savings in shares of private companies, and has built its pension system in such a way that their citizens care of the amounts of savings and have the choice of two alternatives: either to live in old-age minimum minuscule obtained in the form of social assistance from the state, or to live in full prosperity, through the use of accumulated funds in personal retirement accounts. The system of social security in the countries of North America focuses not on the state support of the citizens, and on their voluntary investment of own frees funds in private equity funds, or so-called mutual funds (mutual funds), which not only earn money but also multiply them in time.

The percentage of shares in the saving portfolio of the private investors in different countries is different. Such for example, in CIS countries it's $0,5 \%$, in Japan it's $6 \%$, in Germany it's 33\%, in USA it's 55\%, in Australia it's 57\% and in Canada it's 61\%.[1]

It is necessary to add that in Japan, unlike the CIS money is not kept in the home, they are stored in the bonds, which is also quite important role in financing private corporations and their government. On the sum of ownership obligations, Japan takes the first place in the world.

How is the process of investing in the instruments of the stock market through mutual funds?

Mutual funds are mutual investment company of open type, which by issuing securities to raise funds from ordinary citizens, who then are invested in stocks, or bonds. Each mutual Fund at the beginning of its activity is an investment portfolio that is adjusted annually. Shares and bonds included in the portfolio are divided into smaller portfolios, which are called indexes. Here in such indices or index funds invest in small-scale investors. The average number of index funds EOF ranges from 5 to 15 pieces, and depends on the funds of this mutual Fund and from the objectives pursued its escape.

Deciding to open an account in a mutual Fund, the investor contributes to the account of the mutual Fund money and obtained the shares of this mutual Fund. Further, through consultations with the Fund Manager, the investor chooses for its investment, the index Fund. This index-the Fund has an approximately 15 to 30 stocks, bonds, or both. Every six months, the investor receives a statement of his index Fund, by which he can follow the dynamics of changes of its current profit or loss. If necessary, the investor is entitled to change its index Fund, but each such change has additional operating costs.

So, choosing index-Fund investor within one or two days are invested in the instruments of this index-Fund within a few days the investor receives an extract from your account, where we specified the exact number of purchased shares and the price of their purchase.

One of the main advantages of mutual funds for small investors, it is the low cost of maintenance of the portfolio. To open such an account does not need to immediately invest large funds to buy shares or bonds, as it happens, for example, in brokerage companies. Buying stock through a brokerage companies, the investor is obliged to pay for each transaction commission fee, which varies between $\$ 15$ and buying less than 50 shares in this case is not interesting in view of the high cost of this operation. In a mutual Fund fees are missing and everything is a little different. The investor can buy not only less than 50 shares, but can afford to buy only 1 or even $1 / 2$ shares without raising the cost of their operations, which gives him the opportunity to open an account for the acquisition of shares, even with $\$ 1,000$.[2, Alekhin, 1991]

Fees of mutual funds are charged in two ways: installment upon opening, or so-called load and operating costs incurred for conducting of operations of purchase/sale of stock instruments. There are also funds without load, the costs of such a Fund consist only of operating expenses, but their size is slightly increased, and they additionally include also the expenditures for administration and marketing company. Total annual costs standard EOF charge of their investors varies only between $2 \%-4 \%$ of the investment sum. [2, Alekhin, 1991]

Customer service in mutual funds is two directions. At first, the amount of cash to be paid as a lump sum, and then grows in time. In the second case, the investor can invest small amounts every month, say once a month for $\$ 50$, and for a long period of time aims accumulation.

If we study the statistics of the U.S. stock market, which is one of the most developed in the world, we will see that the shares are among the most profitable tools on the market, the yields approximately twice the yield of the bonds. And if we add to this the possibility of reinvesting profits, then the table of compound interest to find that our initial Deposit within only 5 years old may at least be doubled.

Table 1. The rate of profit

\begin{tabular}{|c|c|c|c|c|}
\hline $\begin{array}{c}\text { PRIVATE } \\
\text { Age }\end{array}$ & $5 \%$ & $10 \%$ & $15 \%$ & $20 \%$ \\
\hline 15 & $\$ 100$ & $\$ 100$ & $\$ 100$ & $\$ 100$ \\
\hline 20 & $\$ 128$ & $\$ 161$ & $\$ 201$ & $\$ 249$ \\
\hline 25 & $\$ 163$ & $\$ 259$ & $\$ 405$ & $\$ 619$ \\
\hline 30 & $\$ 208$ & $\$ 418$ & $\$ 814$ & $\$ 1541$ \\
\hline 40 & $\$ 339$ & $\$ 1083$ & $\$ 3292$ & $\$ 9540$ \\
\hline 50 & $\$ 552$ & $\$ 2810$ & $\$ 13318$ & $\$ 59067$ \\
\hline 60 & $\$ 899$ & $\$ 7298$ & $\$ 53877$ & $\$ 365726$ \\
\hline 65 & $\$ 1147$ & $\$ 11739$ & $\$ 108366$ & $\$ 910044$ \\
\hline
\end{tabular}

Now let's look at the process of accumulating funds over a long period of time. In order to attract citizens to funded pension schemes, the government of North American countries went through a very interesting way. On each invested capital, on the laws regulating the cumulative pension system, the government pays $20 \%$, and the profit 
received during the year is not subject to taxation. If investors start to invest money during their working lives and keep their savings account in a mutual Funds prior to their retirement, they receive $20 \%$ of the loan from the invested funds and uses $100 \%$ of the received profit for reinvestment. [4, Gitman, 1999] Then after retirement, they return to the state $20 \%$, got from them during the opening of the accumulative account, and pay tax on income derived from their funded activities. Let us extend the range of our investment in time and look at the table of compound interest, what income we can get retired, if our initial Deposit of just $\$ 100$ (20\% allowance from the state in the calculation will not be accepted).

\section{Advantages of mutual funds over other financial instruments on the Russian market}

The emergence of a mechanism for collective investments was due to the fact that independent operations on financial markets were often not available to private investors. The main reason is the lack of knowledge in this area, the need to devote this kind of activity a significant amount of time, the high costs of building an effectively diversified portfolio. In addition, because of the nature of the infrastructure debt market participants often unprofitable to work with the funds of small investors, and some editions of the government are simply not designed to accommodate additional physical violence. The creation of mutual funds was to help overcome these barriers and encourage investment activity of the population.

In the developed countries the institute for collective investments is very popular and is the primary method of public participation in the operations in the financial market. According to the Investment Company Institute, as of mid-2002. 54.2 million, or $49.6 \%$ of American households and one-third of American - 94.9 million people - owned mutual funds. At the end of last year, the number of mutual funds in the United States was 8269 (for the third year in a bear market it decreased by 38 funds), and their net assets 6.4 trillion. \$. [5, Kidwell D. S., Peterson, R. L., Blackwell D. U., 2000]

1. Funds shareholders are professional management. If you follow the formula "boots must stitch pie cobbler, pies and oven - pyrogenic", it turns out that the money must be managed by the master of this case, i.e., the money manager. On the one hand, really sounds convincing that to achieve the best of the investment should be carried out on a professional basis, because only a professional will be able to constantly monitor the situation on the market and to change the structure of the portfolio in response to the emergence of more favorable for capital growth opportunities. But on the other hand, practice shows that the skill of the stock market is very often confused with luck.

2. Diversification of assets. Fund Manager the company in accordance with the stated investment objective of building a portfolio that can be presented more than a dozen instruments. For the private investor and independent creation of a similar portfolio structure would require significant disposable sum of money and would cost much more expensive (with purchase of large blocks of securities expenses for brokerage fee below).

Many novice investors know that to reduce the risk on the portfolio it is necessary to resort to diversification, but underneath they understand the principle of "never put all your eggs in one basket", which is implemented through the purchase of "salad" of randomly selected assets. But effective, and not a primitive diversification implies that the components of the portfolio are chosen according to a negative correlation (to increment by one the instruments offset losses on another), so the establishment of a well-diversified portfolio can be challenging for an inexperienced investor.

3. Strict control from the state protects the rights of investors. Since 1996, when started the first mutual funds in Russia, not been a single documented case of deception or fraud. Fund's property that is in share ownership shareholders, is stored in Special Depositaries. The management company, to manage the Fund's assets any action, you must get his consent. This separation of powers for storage and disposal of assets of the Fund, as well as the principle of its isolation, implemented through the accounting in the separate balance sheet, allow to prevent possible abuse by the Trustee. If the Special Depositary notices of any violations in the activities of the management company, information about this will be sent to the market regulators. If the violations are not resolved or repeated the market regulator of a Manager threatens suspension or even license revocation. In addition to the Special Depositary kind of control exercised by the Registrar, leading the register of shareholders and the auditor. [3] Thus, we can speak of the multilateral system of control by the market regulator and the companies that make up the infrastructure of the Mutual Fund.

In accordance with the requirements of the market regulator information disclosure management company shall publish its balance sheet and profit and loss account; the balance of the assets of the mutual Fund and the statement of changes in its value, help on NAV (net asset value) and other.[3]

4. For the avoidance of double taxation. Under current law, mutual funds are not legal entities, so they have no obligations to pay tax on the profit. Subject to tax only the income received by owners of shares in their implementation, the difference between the redemption price and purchase price of the unit. The responsibility for determining the tax base and calculation of the amount of the tax to incomes of physical persons received from the sale of investment units, as well as to withhold tax from such income in accordance with sec. 23 of the tax code shall be imposed on a management company. For physical persons - residents income tax rate is $13 \%$, for non-residents is $30 \%$.

Definition of the tax base when selling shares. The financial result of the investment shares (income or loss) is defined as the difference between the amount received from the redemption of shares, and the documented cost of 
acquisition, including expenses recoverable from the management company. Property tax deduction provided for Art. 220 of the tax code, does not apply because the management company keeps records acquired by individuals units and has all the necessary information about the costs associated with the purchase and redemption of shares.

The determination of the taxable base for the conversion (exchange) of shares. The rules of trust management of public or interval mutual Fund for the holders of units may be able to exchange them for shares of another public or interval Fund being under control of the same management company. In accordance with the article 567 CCRF (Civil Code of Russian Federation) under a barter contract (conversion) each of the parties undertakes to transfer the ownership of the other hand one good in exchange for another, so a barter agreement (conversion), the rules about the sale. As in the process of conversion shares are sold one and buy a new unit, each of the parties is considered as a member of two transactions. Thus, at the time of transfer of the exchanged shares in investor tax base for income tax, which is calculated as the difference between the selling price of the share and the cost of its acquisition.

5. A simple mechanism of investment. The investor in accordance with the rules of the Fund sends the application for purchase, redemption or exchange of shares of the management company or its agents. To monitor the change in the value of shares he may, by accessing the website of the criminal code or referring directly to it or to its agents on request of the shareholder, they are required to provide a certificate of NAV and the last calculated value of shares, a report on the value of the property constituting the mutual Fund, and its balance sheet.

Compensation in connection with the implementation of the share of Open Mutual Fund is made not later than 15 days from the date of redemption of shares, and in case of implementation of the share of Interval Mutual Fund - not later than 15 days from the deadline for receiving applications for redemption. [6, Milovidov, 1996]

The most important breakthrough in the development of the domestic industry collective investments can be considered as on the 31 January 2004 RTS first stock exchange trading of shares of the Mutual Fund. It was the "Pioneer Fund" - "Mutual Fund of Dividend stocks and corporate bonds" under the management of CJSC "REGION asset Management". The organization of the treatment units the exchange will significantly expand the geography of potential shareholders (shares can be carried out through any broker that is a member of the exchange), and the presence of a liquid secondary market will provide investors with the opportunity to buy and sell shares of Interval Mutual Funds at any time. In addition, due to the electronic document management system will increase the efficiency of settlements with shareholders - 3-15 days to 1 day. [7, Tobin D., 2004]

\section{Results}

Saving money in a mutual fund, but not in the Bank or under the «planks», plays an important role for the small investor. Consider all of them:

First. Investor lays funds for the further existence and in case of unforeseen situations (legal incapacity, bankruptcy, etc.) provides a comfortable existence in the future.

Second. Due to the complex percent $100 \%$ increase of the invested funds is approximately 5 years.

Third. Thanks to investments in financial instruments, any citizen has the opportunity to own assets of private and foreign enterprises.

\section{Conclusions}

The conclusion can be only one: to accumulate necessary as early as possible in time and limited initial installment not worth it. Build your savings system is based on the initial amount, say $\$ 1,000$ and monthly investment of $\$ 50$ - $\$ 100$ on the size of the received income per month. To afford this program until may not all, but without making drastic new measures in managing our financial resources, we can not expect, that in the future we will be able to earn a decent old age.

If you compare the pension provision of New and Old world, unlike the last first tries to solve future problems of their citizens by raising funds in their financial markets. Creating pension funds, the New world forces the citizens to think about their future costs and not to shift the burden of pension payments to the budget of the country and a young population. This approach has led to the fact that every second inhabitant of the USA, directly or indirectly, is a participant of the stock market and makes work their capital more actively, thus, developing companies and the economy is better and faster than the Europeans. According to statistics, the assets of investment and pension funds in the United States working on the stock market total more than $\$ 5$ trillion., while the European funds with difficulty can be counted stock of assets worth more than $\$ 1$ trillion.

Mass attraction of private deposits in the financial system in North America gives her the following benefits:

- in-first, the welfare state due to the wealth of its citizens;

- secondly, increases capitalization of North American stock markets, compared with the European one;

- thirdly, the North American companies, each employee has at its disposal the company's shares, and this in turn makes the workers of the company to work with more interest and performance (it is this some economists explain the high productivity of American workers, in comparison with European).

\section{REFERENCES}

[1] Financing growth: the choice of methods in a changing world 
/ Lane. from English. - M: Palgrave Macmillan, 2002, - p.4.

[2] Alekhin B. I. the securities Market. Introduction to stock operation. - M.: Finance and statistics, 1991. - p. 31.

[3] Federal law No. 156-FZ of November 29, 2001. "About investment funds"

[4] Gitman L., Jank M. fundamentals of investments. - M.: Delo, 1999. - S. 642
[5] Kidwell D. S., Peterson, R. L., Blackwell D. U. Financial institutions, markets and money. St. Petersburg: Publishing house "Peter", 2000

[6] Milovidov C. D. Mutual funds. - M: Ancil, Infra-M, 1996

[7] Tobin D. Financial intermediaries. In Proc. of Economic theory, Ed. j. Itwell, M Of Milgate, P. Newman Lane. from English. / Scientific. Ed. Corr.-Corr. RAS C. S. Avtonomov. - M.: Infra-M, 2004. - pp.322-357. 